\title{
Strategi Pemenuhan Hak Pelayanan Penitipan Barang bagi Tahanan di Masa Pandemi Covid-19
}

\author{
Yuliana Novitasari $^{\varpi_{1}}$, Arisman ${ }^{2}$ \\ ${ }^{1}$ Manajemen Pemasyarakatan, Politeknik Ilmu Pemasyarakatan \\ 2Badan Pengembangan Sumber Daya Manusia Hukum dan Hak Asasi Manusia
}

\begin{abstract}
ABSTRAK
Permasalahan di Rutan Kelas I Surakarta yaitu dalam pemenuhan hak pelayanan penitipan barang di masa pandemi covid-19 sering terjadi penyelundupan oleh orang yang tidak bertanggung jawab. Perlu adanya strategi khusus agar dapat memperoleh penyelesaian secara ilmiah dengan menerapkan analisis SWOT. Penelitian ini bertujuan untuk mengetahui strategi pemenuhan hak pelayanan penitipan barnag dalam mencegah penyelundupan di Rutan Kelas I Surakarta dengan menggunakan analisis SWOT. Metode penelitian menggunakan metode campuran dengan melalui pendekatan deskriptif analitik. Teknik pengumpulan data diperoleh melalui observasi, sebar kuestioner, dan melakukan analisis faktor internal dan eksternal yang terdiri dari kekuatan, kelemahan, peluang, dan ancaman. Hasil analisis SWOT menunjukkan bahwa kuadran IFAS dan EFAS di kuadran I yaitu berada diantara S-O (strengths dan opportunities). Nilai IFAS adalah $(0,56823)$ terletak pada sumbu axis kuadran SWOT dan nilai EFAS adalah $(0,09444)$ terletak pada sumbu ordinat kuadran SWOT. Sehingga dengan hasil perhitungan maka Rutan Kelas I Surakarta dapat menerapkan strategi agresif dimana strategi tersebut menggunakan kekuatan untuk memanfaatkan peluang. Hasil penelitian yaitu dapat dengan memanfaatkan lokasi rutan yang sering mendapat kunjungan dari instansi lain, memanfaatkan jumlah petugas dalam melakukan penggeledahan kamar hunian, memanfaatkan hubungan baik dengan APH dalam meningkatkan pengamanan, dan memanfaatkan hubungan baik dengan masyarakat untuk meningkatkan pelayanan penitipan barang.
\end{abstract}

\section{Kata kunci:}

Analisis SWOT, penanganan, permasalahan, rutan, strategi

\begin{abstract}
The problem at the Class I Rutan Surakarta is that in fulfilling the right to deposit services for goods during the Covid-19 pandemic, smuggling often occurs by irresponsible people. There needs to be a special strategy in order to obtain a scientific solution by applying a SWOT analysis. This study aims to determine the strategy of fulfilling the right to new care services in preventing smuggling in the Class I Rutan Surakarta by using a SWOT analysis. The research method uses a mixed method with a descriptive analytic approach. Data collection techniques are obtained by observing, distributing questionnaires, and analyzing internal and external factors consisting of strengths, weaknesses, opportunities, and threats. The results of the SWOT analysis
\end{abstract}


show that the IFAS and EFAS quadrants in quadrant I are between S-O (strengths and opportunities). The IFAS value is (0.56823) located on the SWOT quadrant axis and the EFAS value is (0.09444) located on the SWOT quadrant ordinate axis. So that with the calculation results, the Class I Rutan Surakarta can implement an aggressive strategy where the strategy uses strength to take advantage of opportunities. The result of this research is to utilize the location of the detention center which frequently receives visits from other agencies, to utilize the number of officers in conducting searches of residential rooms, to utilize good relations with APH in increasing security, and to take advantage of good relations with the community to improve goods storage services.

Keywords: SWOT analysis, handling, problems, detention, strategy

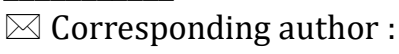

Email Address : yuliananovita036@gmail.com

"Received 12, Agustus 2020, Accepted 15, Januari 2021, Published 06, Februari 2021"

\section{Pendahuluan}

Munculnya pandemi Covid-19 saat ini telah menggemparkan seluruh dunia yaitu dimana virus ini telah ditemukan pertama kali di daerah Wuhan Cina pada akhir tahun 2019. Seluruh masyarakat dunia khawatir dengan adanya wabah tersebut, terlebih dengan adanya pengumuman yang dikeluarkan oleh WHO bahwa pandemi yang yang melanda dunia ini merupakan sebagai pandemi global (Dong et al., 2020). Pada awal tahun 2020, Negara Indonesia ikut merasakan wabah pandemi covid-19 yang juga telah dialami hampir 120 negara di seluruh dunia (Dida et al., 2021). Dampak yang ditimbulkan dari wabah ini sangat luar biasa, khususnya di bidang perekonomian, Indonesia mengalami penurunan drastis dilihat dari pertumbuhan ekonomi Indonesia sebelum pandemi diperkirakan mencapai 5,3\% namun akibat pandemi terjadi kemerosotan hingga dibawah 2\% (Hadiwardoyo et al., n.d., 2020). Selain penurunan ekonomi, permasalahan yang terjadi yaitu masyarakat tidak dapat leluasa bergerak karena cara persebaran virus ini sangat mudah dan mengakibatkan banyak masyarakat mudah tertular. Himbauan dari pemerintah Indonesia untuk mencegah persebaran virus tersebut yaitu dengan menerapkan protokol kesehatan dan melarang masyarakat untuk bepergian jauh. 
Adanya pandemi Covid-19 juga berdampak di lingkungan pemasyarakatan dimana di dalam lingkungan tersebut harus diterapkan juga protokol kesehatan. Penerapan protokol kesehatan ini ditunjukkan dengan adanya perubahan kebijakan dimana sebelum ada pandemi covid-19, tahanan dan narapidana mendapat pelayanan tahanan seperti hak mendapatkan kunjungan dari keluarga. Akan tetapi karena masa pandemi saat ini, maka layanan tersebut ditiadakan demi mencegah persebaran virus covid-19 yang kemungkinan dapat menyebar di dalam rumah tahanan Negara maupun di lembaga pemasyarakatan. Adanya perubahan kebijakan tersebut sangat berdampak terhadap sebagian besar tahanan maupun narapidana dimana mereka tidak dapat berjumpa dengan keluarga mereka sehingga mereka merasa kurang kepedulian dari keluarga. Salah satu kebijakan yang dibuat sebagai alternatif pengganti layanan kunjungan yaitu adanya layanan penitipan barang bagi tahanan dan narapidana. layanan tersebut diharapkan dapat menjadi pendorong bagi tahanan maupun narapidana untuk menjadi lebih baik meskipun tidak dapat bertatap langsung dengan keluarga mereka.

Sebagai suatu instansi pemerintah yang berorientasi dalam melayani masyarakat tentu menyadari bahwa keberlangsungan organisasi harus dipertahankan. Meskipun banyak peluang dalam memajukan organisasi, akan tetapi tidak jarang juga ditemukan permasalahan-permasalahan yang dapat menghambat kemajuan organisasi tersebut. Setiap instansi akan selalu dihadapkan dalam permasalahan-permasalahan yang berbeda berdasarkan lingkup tugas pokok dan fungsi masing-masing organisasi. Begitu juga permasalahan yang dihadapi unit pelaksana teknis di lingkungan pemasyarakatan. Permasalahan di pemasyarakatan yang masih ada hingga saat ini yaitu overcapacity. Dengan adanya overcapacity di masa pandemi covid-19 mengakibatkan pemasyarakatan harus membuat kebijakan baru agar dapat mencegah persebaran covid-19. Salah satu cara mencegah persebaran covid-19 di rumah tahanan negara yaitu dengan membuat kebijakan pelayanan penitipan barang.

Adanya layanan penitipan barang tentu memiliki dampak yang positif bagi tahanan dan narapidana. Akan tetapi, tidak jarang kebijakan yang bertujuan baik sering disalahartikan 
oleh orang-orang yang tidak bertanggung jawab untuk mencari celah dalam berbuat keburukan. Permasalahan-permasalahan akan muncul di dalam instansi rumah tahanan negara maupun lembaga pemasyarakatan seperti adanya penyelundupan narkoba ketika pengunjung melakukan penitipan barang. Narkoba merupakan zat yang apabila dikonsumsi, baik di minum, dihirup, maupun disuntikan, memiliki pengaruh terhadap pikiran, suasana hati atau perasaan, dan perilaku seseorang (AMANDA et al., 2017). Soerdjono Dirjosisworo (1986) menyatakan bahwa narkotika merupakan zat yang bisa memberikan dampak tertentu bagi yang menggunakannya dengan memasukkan kedalam tubuh. Masalah penyalahgunaan narkoba mempunyai dimensi yang luas dan kompleks, baik dari sudut medik, psikiatri, kesehatan jiwa, maupun psikososial (Sanger, 2013)

Perlu kita ketahui Rutan atau biasa disebut Rumah Tahanan Negara berdasarkan Permenkumham nomor 6 Tahun 2013 dapat diartikan bahwa suatu tempat dikumpulkannya para tersangka atau terdakwa untuk dilakukan penahanan dalam proses pidana meliputi penyidikan, penuntutan, dan pemeriksaan dalam sidang pengadilan. Panggilan bagi para tersangka dan terdakwa yang berada di rumah tahanan negara biasa disebut tahanan.

Analisis permasalahan instansi yang akan dibahas yaitu unit pelaksana teknis di lingkungan pemasyarakatan khususnya yaitu Rutan Kelas I Surakarta. Rutan Kelas I Surakarta sudah tidak asing lagi di benak kita. Rutan Kelas I Surakarta terletak di tengah kota Surakarta tepatnya di jalan raya Slamet Riyadi No.18 Surakarta dengan luas bangunan $8.110 \mathrm{~m}^{2}$. Rutan Kelas I Surakarta berbatasan sebelah utara yaitu gang kampung baru, sebelah selatan yaitu Jalan Slamet Riyadi, sebelah barat dibatasi gang antara rutan dengan Bank BPD, dan sebelah timur dibatasi gang rutan dengan Bank Mandiri.

Beberapa permasalahan yang mungkin terjadi di Rutan Kelas I Surakarta salah satunya yaitu dengan diberlakukan kebijakan penitipan barang dapat dimungkinkan adanya penyelundupan narkoba oleh orang yang tidak bertanggung jawab, oleh karena itu perlu dilakukan analisis SWOT untuk mengetahui strategi apa yang dapat diambil dalam 
mengatasi permasalahan-permasalahan khususnya strategi pemenuhan hak pelayanan penitipan barang dalam mencegah penyelundupan narkoba di Rutan Kelas I Surakarta.

Analisis SWOT merupakan suatu pendekatan yang sudah dikenal oleh manajer ketika melakukan analisis terhadap suatu organisasi (Yuva Naila \& S Bekti Istiyanto, 2019). Menurut Rangkuti, 2009 dalam (Warren G. A. Luntungan da Hendra N. Tawas, 2019), Analisis SWOT adalah analisis terhadap kekuatan, kelemahan, peluang, dan ancaman yang dimiliki dan dihadapi perusahaan"). Dalam (Purnama \& Budi, 2017) analisis SWOT berupa analisa situasi dan juga kondisi yang bersifat deskriptif yang memberi suatu gambaran. Analisa ini menempatkan situasi dan juga kondisi sebagai sebagai faktor masukan, lalu kemudian dikelompokkan menurut kontribusinya masing-masing dalam perusahaan berguna dalam menetukan strategi perusahaan yang akan dijalankan. Dengan melihat faktor internal dan eksternal dalam suatu perusahaan yaitu kekuatan (Stengths), peluang (Opportunities), kelemahan (Weaknesses), dan ancaman (Threats). Penerapan analisis SWOT perlu dilakukan oleh seorang pimpinan dengan tujuan untuk berpikir strategis dalam menyelesaikan permasalahan yang dihadapi. Analisis SWOT juga berfungsi untuk menggolongkan persoalan-persoalan internal dan eksternal sehingga manajer mampu mengidentifikasi adanya permasalahan yang akan dihadapi maupun untuk diminimalisir (Yuva Naila \& S Bekti Istiyanto, 2019). Juga, dalam (Kusumawardani \& Sediyono, 2016) analisa SWOT merupakan salah satu cara dalam menyusun strategi perusahaan atau organisasi. Analisis SWOT dapat dilakukan dengan cara menggambarkan kondisi, bisa juga dengan cara mengevaluasi suatu masalah. SWOT adalah akronim untuk kekuatan (strenghts), kelemahan (weakness), peluang (opportunities), dan ancaman (threats) dari lingkungan eksternal perusahaan (Lastina \& Sunarni, 2019).

Berdasarkan latar belakang dan uraian di atas, penulis memutuskan untuk melakukan penelitian mengenai analisis SWOT untuk mengetahui strategi pemenuhan hak pelayanan penitipan barang dalam mencegah penyelundupan narkoba di Rutan Kelas I Surakarta. Dimana strategi tersebut diharapkan petugas dapat memenuhi hak yang dimiliki tahanan dan narapidana yaitu berupa pelayanan penitipan barang dengan memperhatikan 
permasalahan yang mungkin ditimbulkan dari pelayanan tersebut. Dengan adanya analisis SWOT yang dilakukan oleh peneliti, semoga penulis dapat memperoleh manfaat yaitu dapat mengetahui strategi pemenuhan hak pelayanan penitipan barang dalam mencegah peredaran narkoba di Rutan Kelas I Surakarta. Manfaat yang diperoleh bagi petugas yaitu dapat menerapkan strategi-strategi tersebut untuk memberikan pelayanan yang terbaik dengan memperhatikan keamanan di dalam rutan. Kemudian manfaat yang diperoleh bagi pembaca yaitu dapat menambah pengetahuan tentang strategi pemenuhan hak tahanan dalam memberikan pelayanan penitipan barang di Rutan Kelas I Surakarta.

\section{Metode Penelitian}

Penelitian ini dilakukan di salah satu Unit Pelaksana Teknis di lingkungan Pemasyarakatan yang berlokasi di Rutan Kelas I Surakarta. Penelitian ini dilakukan dalam kurun waktu 3 minggu. Metode penelitian yang dilakukan menggunakan metode campuran yaitu metode kualitatif dan kuantitatif dengan melakukan pendekatan deskriptif analitik. Teknik pengambilan data dalam metode kualitatif dilakukan dengan cara observasi lapangan dimana peneliti memperoleh informasi dengan melakukan pengamatan di lingkungan Rutan Kelas I Surakarta. Teknik pengambilan data dalam metode kuantitatif dilakukan oleh peneliti dengan menyebar kuestioner kepada petugas Rutan Kelas I Surakarta. Sumber data diperoleh dari sumber data primer. Sumber data primer diperoleh dengan melakukan sebar kuestioner dan observasi lapangan.

Metode analisis data dilakukan dengan melakukan analisis SWOT dimana peneliti melakukan analisis faktor internal dan eksternal yang ada di Rutan Kelas I Surakarta. Analisis SWOT tersebut terdiri dari kekuatan, kelemahan, peluang, dan ancaman. Analisis SWOT dilakukan untuk mengetahui strategi pemenuhan hak pelayanan penitipan barang bagi tahanan dalam mencegah penyelundupan narkoba di Rutan Kelas I Surakarta.

Sumber data kuestioner disebar kepada tiap-tiap perwakilan petugas Rutan Kelas I Surakarta dengan jumlah populasi 147 petugas dengan sampel 108 petugas yang diperoleh dari perhitungan rumus slovin dengan teknik pengambilan sampel random. 
Analisis SWOT merupakan suatu cara untuk mengidentifikasi berbagai faktor dengan memaksimalkan kekuatan dan peluang, tetapi juga mencegah kelemahan dan ancaman khususnya yang ada di Rutan Kelas I Surakarta (Wardah \& Kota, 2020). Analisis SWOT terdiri dari:

a. Strengths (kekuatan) merupakan macam-macam kekuatan dari dalam yang dimiliki instansi atau kemampuan yang dapat digunakan untuk dasar pengembangan instansi.

b. Weaknesses (kelemahan) adalah keterbatasan dari dalam instansi baik dalam finansial, sumber daya, penerapan teknologi sehingga mempengaruhi keberlangsungan instansi.

c. Opportunities (peluang) adalah situasi penting yang berasal dari luar memiliki pengaruh yang menguntungkan bagi instansi.

d. Threats (ancaman) adalah keadaan yang tidak menguntungkan instansi dari luar sehingga dapat menghamba kemajuan instansi(Wardah \& Kota, 2020).

\section{Hasil dan Pembahasan}

Rutan Kelas I Surakarta merupakan salah satu Unit Pelaksana Teknis Pemasyarakatan yang berada di kantor wilayah Jawa Tengah. Salah satu isu permasalahan yang sering muncul di Rutan Kelas I Surakarta yaitu pemenuhan hak pelayanan penitipan barang bagi tahanan sering terjadi penyelundupan benda terlarang seperti narkoba. Adanya permasalahan tersebut, maka perlu dilakukan pengkajian secara ilmiah dalam menemukan cara penanganan dan pencegahan peredaran narkoba di Rutan Kelas I Surakarta. Oleh karena itu, penulis melakukan kajian secara ilmiah dengan melakukan analisis SWOT dalam menemukan stategi pemenuhan hak pelayanan penitipan barang dalam mencegah penyelundupan narkoba di Rutan Kelas I Surakarta.

\section{Analisis SWOT}

a. Faktor lingkungan internal dengan adanya isu permasalahan adanya penyelundupan narkoba di Rutan Kelas I Surakarta

1. Kekuatan (strength)

a) Lokasi rutan di tengah kota

b) Adanya SOP dalam pelaksanaan penggeledahan

c) Memiliki jumlah petugas terbanyak di kanwil Jawa Tengah 
d) Rutin melakukan penggeledahan kamar hunian

e) Penggeledahan penitipan barang berlapis

2. Kelemahan (weakness)
a) Terjadi overcapacity
b) Waktu pelayanan penitipan barang tidak sebanding dengan jumlah pengunjung
c) Adanya keterlibatan petugas dalam penyelundupan
d) Adanya perbedaan perlakuan terhadap status sosial WBP

b. Faktor lingkungan eksternal di Rutan Kelas I Surakarta

1. Peluang (opportunities)
a) Terjalin hubungan baik antar aparat penegak hukum
b) Adanya kerjasama yang baik dengan masyarakat dalam mendukung proses penitipan barang
c) Penggeledahan kamar secara rutin dengan bekerja sama dengan instansi lain
d) Pengunjung tetap dapat menjalin komunikasi dengan tahanan

2. Ancaman (threats)
a) Adanya penyelundupan barang terlarang yang dilakukan pengunjung
b) Adanya pelemparan barang terlarang dari luar rutan
c) Terjadi kerusuhan dari kelompok tertentu
d) Pandangan negatif dari masyarakat luar

Tabel 1. Analisis Faktor Internal Matriks Internal Faktor Analisis System (IFAS)

\begin{tabular}{|c|c|c|c|c|}
\hline No & Analisis faktor internal & Bobot & Rating & Skor \\
\hline \multicolumn{5}{|c|}{ Kekuatan (Strengths) } \\
\hline 1 & Lokasi rutan di tengah kota & 0,0455 & 4,3 & 0,19565 \\
\hline 2 & $\begin{array}{l}\text { Adanya SOP dalam pelaksanaan } \\
\text { pengamanan }\end{array}$ & 0,0909 & 3,6 & 0,32724 \\
\hline 3 & $\begin{array}{l}\text { Memiliki jumlah petugas terbanyak di } \\
\text { kanwil Jawa Tengah }\end{array}$ & 0,1364 & 4,7 & 0,64108 \\
\hline 4 & $\begin{array}{l}\text { Rutin melakukan penggeledahan kamar } \\
\text { hunian }\end{array}$ & 0,1364 & 2,8 & 0,38192 \\
\hline 5 & Penggeledahan penitipan barang berlapis & 0,0909 & 3.5 & 0,31815 \\
\hline \multicolumn{4}{|c|}{ TOTAL KEKUATAN } & 1,86404 \\
\hline \multicolumn{5}{|c|}{ Kelemahan (Weakness) } \\
\hline 6 & Terjadi overcapacity & 0,1364 & 4,1 & 0,55924 \\
\hline 7 & $\begin{array}{l}\text { Waktu pelayanan penitipan barang tidak } \\
\text { sebanding dengan jumlah pengunjung }\end{array}$ & 0,1364 & 3,5 & 0,4774 \\
\hline 8 & $\begin{array}{l}\text { Adanya keterlibatan petugas dalam } \\
\text { penyelundupan }\end{array}$ & 0,0909 & 1,8 & 0,16362 \\
\hline 9 & $\begin{array}{l}\text { Adanya perbedaan perlakuan terhadap } \\
\text { status sosial WBP }\end{array}$ & 0,0455 & 2,1 & 0,09555 \\
\hline \multicolumn{4}{|c|}{ TOTAL KELEMAHAN } & 1,29581 \\
\hline
\end{tabular}


Pada table 1. Penulis dapat mengetahui bahwa hasil perhitungan diperoleh nilai tertinggi kekuatan sebesar 0,64108 yaitu memiliki jumlah petugas terbanyak di kanwil Jawa Tengah. Urutan kedua dengan nilai sebesar 0,38192 yaitu rutin melakukan penggeledahan kamar hunian. Urutan ketika berdasarkan perhitungan yang dilakukan yaitu memperoleh nilai 0,32724 yaitu adanya SOP dalam pelaksanaan pengamanan. Urutan keempat dengan nilai 0,31815 yaitu penggeledahan penitipan barang berlapis. kemudian urutan terakhir dari hasil perhitungan yaitu memperoleh nilai 0,19565 yaitu lokasi rutan di perkotaan. Sehingga diperoleh hasil penjumlahan dari skor kekuatan maka diperoleh nilai sebesar 1,86404 .

Sedangkan perhitungan nilai kelemahan yang ada di Rutan Kelas I Surakarta maka dapat diurutkan dengan nilai tertinggi sebesar 0,55924 yaitu Terjadi overcapacity. Urutan kedua dengan nilai sebesar 0,4774 yaitu Waktu pelayanan penitipan barang tidak sebanding dengan jumlah pengunjung. Urutan ketiga berdasarkan perhitungan yang dilakukan yaitu memperoleh nilai 0,16362 yaitu Adanya keterlibatan petugas dalam penyelundupan. Urutan terakhir dari hasil perkalian bobot dengan rating yaitu memperoleh nilai 0,09555 yaitu Adanya perbedaan perlakuan terhadap status sosial WBP. Sehingga diperoleh hasil penjumlahan dari skor kelemahan maka diperoleh nilai sebesar 1,29581.

Berdasarkan perhitungan matriks IFAS maka dapat kita ketahui nilai dari strategi lingkungan internal. Nilai strategi lingkungan internal dapat di hitung melalui rumus yaitu jumlah hasil penjumlahan kekuatan dikurangi jumlah hasil kelemahan sehingga diperoleh hasil yaitu 1,86404 - 1,29581 adalah 0,56823.

b. Analisis Matriks EFAS (eksternal Faktor Analisis System)

Matriks EFAS memiliki fungsi untuk menganalisis faktor-faktor eksternal yang memiliki pengaruh di Rutan Kelas I Surakarta. Matrik EFAS diperoleh dengan melakukan identifikasi faktor dari luar yang dihadapi di Rutan Kelas I Surakarta. Matriks tersebut menunjukkan adanya peluang dan ancaman yang ada di luar Rutan kelas I Surakata dimana telah disajikan dalam tabel berikut. 
Tabel 2. Analisis Faktor Eksternal

Matriks Eksternal Faktor Analisis System (EFAS

\begin{tabular}{|c|c|c|c|}
\hline No Analisis faktor internal & Bobot & Rating & Skor \\
\hline \multicolumn{4}{|l|}{ Peluang (Opportunity) } \\
\hline $\begin{array}{l}\text { Terjalin hubungan baik antar aparat } \\
\text { penegak hukum }\end{array}$ & 0,1667 & 4,1 & 0,68347 \\
\hline $\begin{array}{l}\text { Adanya kerjasama } \\
\text { masyarakat dalam } \\
\text { penitipan barang }\end{array}$ & 0,1667 & 2,6 & 0,43342 \\
\hline $\begin{array}{l}\text { Dilaksanakan penggeledahan kamar secara } \\
\text { rutin dengan bekerja sama dengan instansi } \\
\text { lain }\end{array}$ & 0,1111 & 4,4 & 0,48884 \\
\hline $\begin{array}{l}\text { Pengunjung tetap dapat berhubungan } \\
\text { dengan tahanan }\end{array}$ & 0,0556 & 2,7 & 0,15012 \\
\hline TOTAL PELUANG & & & 1,75585 \\
\hline \multicolumn{4}{|l|}{ Ancaman (Treaths) } \\
\hline $\begin{array}{l}\text { Adanya penyelundupan barang terlarang } \\
\text { yang dilakukan pengunjung }\end{array}$ & 0,1667 & 3,1 & 0,73348 \\
\hline $\begin{array}{l}\text { Adanya pelemparan barang terlarang dari } \\
\text { luar rutan }\end{array}$ & 0,1667 & 4,4 & 0,51677 \\
\hline Terjadi kerusuhan dari kelompok tertentu & 0,0556 & 1,8 & 0,10008 \\
\hline Pandangan negatif dari masyarakat luar & 0,1111 & 2,8 & 0,31108 \\
\hline TOTAL ANCAMAN & & & 1,66141 \\
\hline
\end{tabular}

Berdasarkan table 2. Peluang dengan nilai tertinggi yang dapat kita ketahui dari hasil perhitungan yaitu diperoleh dengan nilai sebesar 0,68347 yaitu terjalin hubungan baik antar aparat penegak hukum. Urutan kedua dengan nilai sebesar 0,48884 yaitu dilaksanakan penggeledahan kamar secara rutin dengan bekerja sama dengan instansi lain. Urutan ketika berdasarkan perhitungan yang dilakukan yaitu memperoleh nilai 0,43342 yaitu adanya kerjasama yang baik dengan masyarakat dalam mendukung proses penitipan barang. Urutan terakhir dari hasil perhitungan yaitu memperoleh nilai 0,15012 yaitu pengunjung tetap dapat berhubungan dengan tahanan. Sehingga diperoleh hasil penjumlahan dari skor peluang maka diperoleh nilai sebesar 1,75585.

Kemudian, ancaman dengan nilai perhitungan tertinggi diperoleh nilai sebesar 0,73348 yaitu adanya penyelundupan barang terlarang yang dilakukan pengunjung. Urutan kedua 
dengan nilai sebesar 0,51677 yaitu adanya pelemparan barang terlarang dari luar rutan. Urutan ketiga berdasarkan perhitungan yang dilakukan yaitu memperoleh nilai 0,31108 yaitu pandangan negatif dari masyarakat luar. Urutan terakhir dari hasil perhitungan yaitu memperoleh nilai 0,10008 yaitu terjadi kerusuhan dari kelompok tertentu. Sehingga diperoleh hasil penjumlahan dari skor ancaman maka diperoleh nilai sebesar 1,66141.

Berdasarkan perhitungan matriks EFAS maka dapat kita ketahui nilai strategi lingkungan eksternal. Nilai strategi lingkungan eksternal dapat di hitung melalui rumus yaitu jumlah hasil peluang dikurangi jumlah hasil ancaman diperoleh hasil yaitu 1,75585 - 1,66141 adalah 0,09444.

Tabel 3. Hasil Perhitungan IFAS dan EFAS

\section{Hasil perhitungan matriks IFAS dan EFAS}

\begin{tabular}{llll}
\hline Kategori & Sub total & Kategori & Sub total \\
\hline Kekuatan $(\mathrm{S})$ & 1,86404 & Peluang $(\mathrm{O})$ & 1,75585 \\
\hline Kelemahan $(\mathrm{W})$ & 1,29581 & Ancaman $(\mathrm{T})$ & 1,66141 \\
\hline Total $(\mathrm{S}-\mathrm{W})$ & 0,56823 & Total $(\mathrm{O}-\mathrm{T})$ & 0,09444 \\
\hline
\end{tabular}

Gambar 1. Diagram Kuadran Analisis

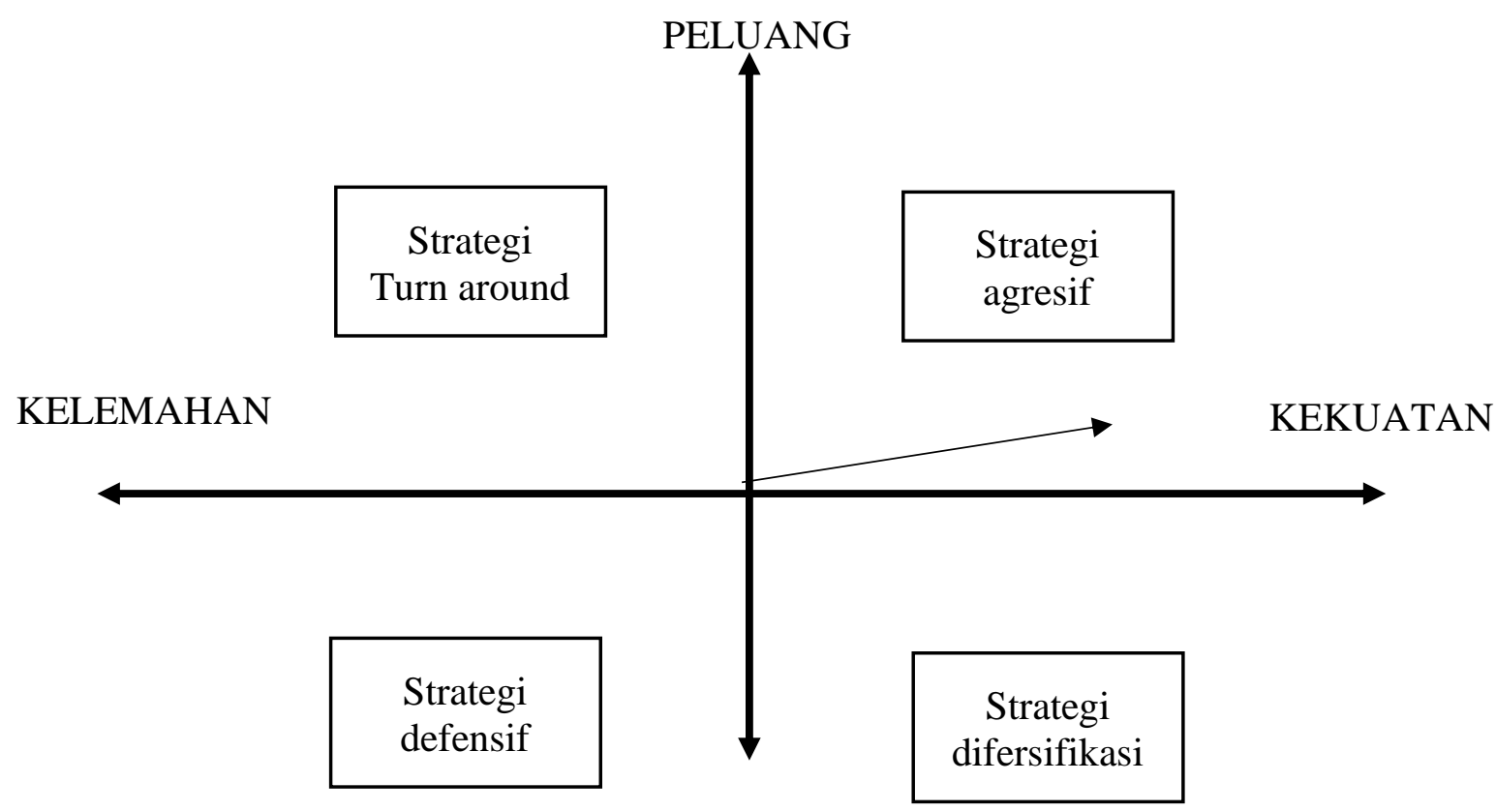


Hasil perhitungan analisis faktor lingkungan yang telah dilakukan memperoleh hasil dimana titik posisi hasil analisis isu permasalahan yang dihadapi oleh Rutan Kelas I Surakarta yaitu pada kuadran I dalam diagram analisis SWOT. Pada kuadran I merupakan kuadran yang terletak diantara kekuatan dan peluang dimana strategi yang digunakan yaitu strategi agresif. Sehingga dapat dijelaskan bahwa Rutan Kelas I Surakarta memiliki kekuatan dan peluang oleh karena itu Rutan Kelas I Surakarta dapat menggunakan kekuatan untuk memanfaatkan peluang yang ada.

\section{Pembuatan matriks SWOT}

Matriks SWOT adalah suatu alat yang digunakan oleh peneliti untuk menyusun faktorfaktor yang berfungsi sebagai alternatif strategis sehingga dapat menggambarkan bagaimana kekuatan dan kelemahan internal suatu organisasi untuk kemudian disesuaikan dengan peluang dan ancaman yang dimiliki dalam mengembangkan strategi pemenuhan hak pelayanan penitipan barang di Rutan Kelas I Surakarta (Muhammad, 2018). Matrik SWOT merupakan alat yang digunakan untuk menyusun faktor-faktor strategis organisasi. Matrik ini dapat menggambarkan secara jelas bagaimana peluang dan ancaman eksternal yang dihadapi organisasi dapat disesuaikan dengan kekuatan dan kelemahan yang dimilikinya. Matriks ini dapat menghasilkan empat set kemungkinan alternatif strategis.

Matriks SWOT ini memberi gambaran tentang bagaimana Rutan Kelas I Surakarta dalam menghadapi permasalahan penyelundupan barang karena penyelundupan sering terjadi ketika masyarakat melakukan penitipan barang dimana layanan tersebut merupakan hak tahanan yang harus dipenuhi sebagai wujud pemenuhan hak asasi manusia di masa pandemi covid-19.

Berikut adalah alternatif strategi pemenuhan hak pelayanan penitipan barang bagi tahanan di masa pandemic covid-19 studi kasus Rutan Kelas I Surakarta. 


\begin{tabular}{|c|c|c|}
\hline & KEKUATAN (S) & KELEMAHAN (W) \\
\hline & $\begin{array}{l}\text { a) Lokasi rutan di } \\
\text { perkotaan } \\
\text { b) Adanya SOP dalam } \\
\text { pelaksanaan } \\
\text { pengamanan } \\
\text { c) Memiliki jumlah petugas } \\
\text { terbanyak di kanwil } \\
\text { Jawa Tengah } \\
\text { d) Rutin melakukan } \\
\text { penggeledahan kamar } \\
\text { hunian } \\
\text { e) Penggeledahan } \\
\text { penitipan } \\
\text { berlapis }\end{array}$ & $\begin{array}{lr}\text { a) Terjadi overcapacity } \\
\text { b) Waktu } & \text { pelayanan } \\
\text { penitipan } & \text { barang } \\
\text { tidak } & \text { sebanding } \\
\text { dengan } & \text { jumlah } \\
\text { pengunjung } & \\
\text { c) Adanya keterlibatan } \\
\text { petugas r dalam } \\
\text { penyelundupan } \\
\text { d) Adanya perbedaan } \\
\text { perlakuan terhadap } \\
\text { status sosial WBP }\end{array}$ \\
\hline $\begin{array}{l}\text { PELUANG (O) } \\
\text { a) Terjalin hubungan baik } \\
\text { antar aparat penegak }\end{array}$ & $\begin{array}{l}\text { STRATEGI SO }(S+0) \\
=1,86404+1,75585 \\
=3,61989\end{array}$ & $\begin{array}{l}\text { STRATEGI WO }(\mathrm{W}+0) \\
=1,29581+1,75585 \\
=3,05166\end{array}$ \\
\hline $\begin{array}{l}\text { hukum } \\
\text { b) Adanya kerjasama yang } \\
\text { baik dengan masyarakat } \\
\text { dalam mendukung proses } \\
\text { penitipan barang } \\
\text { c) Dilaksanakan } \\
\text { penggeledahan kamar } \\
\text { secara rutin dengan } \\
\text { bekerja sama dengan } \\
\text { instansi lain } \\
\text { d) Pengunjung tetap dapat } \\
\text { berhubungan dengan } \\
\text { tahanan }\end{array}$ & $\begin{array}{l}\text { a. Lokasi rutan yang } \\
\text { berada di tengah kota } \\
\text { sehingga sering } \\
\text { mendapat kunjungan } \\
\text { dari instansi pemerintah } \\
\text { lainnya } \\
\text { b. Adanya jumlah petugas } \\
\text { yang paling banyak di } \\
\text { kanwil jawa tengah } \\
\text { maka dapat dilakukan } \\
\text { penggeledahan kamar } \\
\text { hunian secara rutin } \\
\text { dengan APH lainnya } \\
\text { c. Memanfaatkan } \\
\text { hubungan baik dengan } \\
\text { APH dalam } \\
\text { melaksanakan tugas } \\
\text { pengamanan } \\
\text { d. Memanfaatkan } \\
\text { hubungan baik dengan } \\
\text { masyarakat untuk } \\
\text { meningkatkan } \\
\text { pelayanan penitipan } \\
\text { barang }\end{array}$ & $\begin{array}{l}\text { a. Mempertahankan } \\
\text { hubungan baik dengan } \\
\text { masyarakat dalam } \\
\text { mengatur pengunjung } \\
\text { b. Meningkatkan } \\
\text { hubungan baik dengan } \\
\text { instansi lain untuk } \\
\text { menindak petugas } \\
\text { yang tidak disiplin } \\
\text { c. Membangun hubungan } \\
\text { yang baik dengan WBP } \\
\text { tanpa membeda- } \\
\text { bedakan }\end{array}$ \\
\hline $\begin{array}{l}\text { ANCAMAN (T) } \\
\text { a) Adanya penyelundupan } \\
\text { barang terlarang yang }\end{array}$ & $\begin{array}{l}\text { STRATEGI ST }(S+T) \\
=1,86404+1,66141 \\
=3,52545\end{array}$ & $\begin{array}{l}\text { STRATEGI WT }(W+T) \\
=1,29581+1,66141 \\
=2,95722\end{array}$ \\
\hline
\end{tabular}


hukum lainnya seperti kepolisian dan BNN. Oleh karena itu, perlu adanya integrasi antar aparat penegak hukum dalam menciptakan keamanan. Kerjasama keamanan yang biasa dilakukan yaitu melakukan tes urin dalam melacak adanya penggunaan narkoba di dalam rutan.

d. Memanfaatkan hubungan baik dengan masyarakat untuk meningkatkan pelayanan penitipan barang. Di masa pandemi covid-19 ditetapkan kebijakan berupa layanan penitipan barang. Layanan tersebut harus dilakukan penggeledahan secara berlapis oleh petugas untuk mencegah adanya penyelundupan oleh orang yang tidak bertanggung jawab. kebijakan ini dilakukan dengan sepengetahuan pengunjung agar mereka paham mengenai SOP yang ada dengan saling memberikan umpan balik yang saling menguntungkan.

b. Strategi W-O merupakan strategi yang menggunakan kelemahan internal dan memanfaatkan peluang eksternal dengan:

1. Mempertahankan hubungan baik dengan masyarakat dalam mengatur pengunjung. Jumlah penghuni Rutan Kelas I Surakarta sudah melebihi batas, sehingga dalam pelayanan penitipan barang juga perlu adanya penjadwalan yang adil agar dapat mengurangi kerumunan di masa pandemi covid-19. Penjadwalan ini harus dilakukan sosialisasi dengan masyarakat agar tetap terjalin hubungan yang baik.

2. Meningkatkan hubungan baik dengan instansi lain untuk menindak petugas yang tidak disiplin. Dalam menjalankan tugas, perlu adanya menegakkan kedisiplinan agar para petugas dapat menjalankan pekerjaannya dengan sebaik mungkin. Dalam menindak petugas yang bermasalah dan sudah tidak dapat ditoleransi lagi, maka perlu adanya kerjasama dengan instansi APH lain dalam menyelesaikan permasalahan tersebut.

3. Membangun hubungan yang baik dengan WBP tanpa membeda-bedakan. Untuk menciptakan kondisi yang stabil, maka perlu menjalin hubungan yang baik dengan tahanan dan narapidana. hubungan yang baik tersebut dapat mencegah adanya penyelundupan barang terlarang di dalam rutan.

c. Strategi S-T merupakan strategi yang menggunakan kekuatan internal untuk mengurangi atau menghindari pengaruh dari ancaman eksternal dengan:

1. Dengan lokasi yang strategis diharapkan dapat mengurangi peluang terjadinya kajahatan. Letak rutan yang dapat diamati oleh semua orang maka keamananpun dapat diciptakan. Pengunjung yang memiliki tujuan yang tidak baik dapat diawasi karena lokasi rutan yang strategis.

2. Memfokuskan pengamanan dalam mencegah penyelundupan dan pelemparan barang terlarang. Pengamanan yang dilakukan di rutan sudah sangat baik,dimana setiap barang masuk harus melalui X-ray dan dicek manual oleh petugas. Sehingga kecil kemungkinan apabila ditemukan penyelundupan barang terlarang.

3. Meningkatkan SOP penggeledahan untuk mencegah penyelundupan. Di masa pandemi covid-19 ini, penitipan barang sangat tidak tebatas. Oleh karena itu perlu menerapkan SOP agar terhindar dari penyelundupan barang oleh orang yang tidak bertanggung jawab. 
4. Membangun pandangan positif masyarakat dengan memberikan pelayanan terbaik. Pelayanan penitipan barang yang baik oleh petugas dapat memberikan citra yang baik yang diberikan oleh masyarakat.

d. Strategi W-T merupakan suatu taktik atau cara yang ditujukan pada pengurangan kelemahan internal dan menghindar dari ancaman ekternal:

1. Membatasi jumlah pengunjung dengan membagi jadwal untuk menghindari kerumunan di masa pandemi covid-19. Pembatasan jumlah pengunjung juga memiliki tujuan untuk mencegah terjadinya penyelundupan barang terlarang di dalam Rutan Kelas I Surakarta.

2. Memberikan pelayanan terbaik oleh petugas dalam membangun pandangan masyarakat. Pelayanan yang diberikan di masa pandemi covid-19 yaitu pelayanan penitipan barang. Dengan adanya pelayanan ini dapat dilakukan dengan menerapkan 5S untuk membangun pandangan masyarakat yang baik terhadap unit pelaksana teknis pemasyarakatan.

3. Tidak membeda-bedakan tahanan untuk mencegah kerusuhan. Sebagai petugas harus dapat memberikan perhatian yang sama kepada semua tahanan untuk menghindari kerusuhan di dalam rutan. Dengan menciptakan kerukunan di dalam rutan maka dapat terhindar kerusuhan seperti penyelundupan senjata tajam.

4. Mendisiplinkan petugas untuk mencegah adanya keterlibatan petugas dalam penyelundupan barang terlarang. sebagai petugas harus memiliki integritas yang tinggi agar terhindar dari perilaku yang menyimpang seperti melakukan penyelundupan narkoba.

\section{Kesimpulan}

Berdasarkan isu permasalahan yang ada, perlu adanya keterlibatan langsung dan kesadaran yang tinggi oleh petugas dalam memberikan pemenuhan hak tahanan berupa pelayanan penitipan barang dalam mencegah penyelundupan benda terlarang oleh pengunjung yang tidak bertanggung jawab. Petugas perlu mempertahankan integritas dalam menjalankan pekerjaan mereka agar tidak terpengaruh oleh perilaku yang berdampak negatif. Sebagai petugas harus mampu memberikan contoh yang baik bagi tahanan demi menciptakan hubungan yang baik antara petugas, tahanan, narapidana, dan masyarakat. Dengan begitu, diharapkan permasalahan yang ada di Rutan Kelas I Surakarta dapat terselesaikan melalui analisis SWOT.

\section{Referensi :}

AMANDA, M. P., HUMAEDI, S., \& SANTOSO, M. B. (2017). Penyalahgunaan Narkoba Di Kalangan Remaja (Adolescent Substance Abuse). Prosiding Penelitian Dan Pengabdian Kepada Masyarakat, 4(2), 339-345. https://doi.org/10.24198/jppm.v4i2.14392 
Dida, S., Damayanti, T., \& Koswara, A. (2021). Representasi Indonesia pada penanganan COVID-19 di media asing. 5(2), 186-207.

Hadiwardoyo, W., Tinggi, S., Ekonomi, I., \& Barat, J. (n.d.). KERUGIAN EKONOMI NASIONAL AKIBAT PANDEMI COVID-19. 83-92. https://doi.org/10.24853/baskara.2.2.83-92

Muhammad, M. (2018). Analisis SWOT sebagai Strategi Pengembangan Usahatani Buah Naga Merah (Hylocereus costaricensis) Kecamatan Wasile Timur Kabupaten Halmahera Timur. Agrikan: Jurnal Agribisnis Perikanan, 11(1), 28. https://doi.org/10.29239/j.agrikan.11.1.28-37

Wardah, K., \& Kota, D. I. (2020). Jurnal ilmiah akuntansi, manajemen \& ekonomi islam (jamekis) volume 3, no.2, juli 2020.3(2), 73-89.

Yuva Naila, \& S Bekti Istiyanto. (2019). Analisis SWOT Strategi Pengelolaan Reputasi PT. Cowboy Nusantara Jaya. Communications, 1(2), 53-76. https://doi.org/10.21009/communications.1.2.

Kusumawardani, D. M., \& Sediyono, E. (2016). Sistem Informasi Manajemen Rantai Pasok Pariwisata untuk Pembuatan Produk Wisata pada Agen Tour \& Travel dengan Analisis SWOT dan Metode Analytic Network Process (ANP). Jurnal Sistem Informasi Bisnis.

Lastina, D., \& Sunarni, T. (2019). Peningkatan Produktivitas Pemasaran UMKM Catering Mpoek Atik dengan Pendekatan Business Model Canvas dan Analisis SWOT. Jurnal DINAMIKA TEKNIK.

Purnama, D. I., \& Budi, A. (2017). Penerapan Strategi Marketing Menggunakan Analisis SWOT. Industrial Engineering Online Journal.

Sanger, E. C. (2013). PENEGAKAN HUKUM TERHADAP PEREDARAN NARKOBA DI KALANGAN GENERASI MUDA. Lex Crimen . 